Journal of Development and Communication Studies

Vol. 4. No. 2, July 2015-June 2016 ISSN (Online \& Print): 2305-7432. bttp:// www.devcomsjournalmw.org. bttp://dx.doi.org/10.4314/jdcs.v4i2.3

\title{
Adoption of Nutrition and Environment-related technologies by women: Case of IFAD's interventions on Cassava in South-East Nigeria.
}

Margaret J. Koyenikan \& Stephen O. Konkwo, Department of Agricultural Economics and Extension Services, University of Benin, Nigeria.

\begin{abstract}
International Fund for Agricultural Development (IFAD) mainstreamed gender, nutrition and environment issues in her interventions on cassava (Manihot esculenta crants) value chain to achieve food nutrition and health securities. However, implementation strategies could have affected adoption of technologies along the line. This study assessed adoption of nutrition and environment-related technologies/information (N\&E) among women under phases of IFAD's interventions on cassava in south-east Nigeria. Four (4) out of eight (8) States in south-east agro-ecological zone involved in IFAD Assisted Root and Tuber Expansion Programme (RTEP) were purposively selected after rapid appraisal. A total of 280 women were randomly selected (70/State) from four participation-based categories of women identified: participants in both RTEP and Women -in-Agriculture (WIA), WLA only, RTEP only and non-participants in both WLA and RTEP. Data were collected using focus group discussion (FGD) and structured questionnaire. Results show that majority of the women were middle aged ( $\bar{X}=47.37$ years), smallholders $(\bar{X}=2.5 \mathrm{ha})$ and low income earners $(\bar{X}=$ N171218 or $\$ 1063$ /annum). Technologies / information bighly adopted (index $\geq 3$ ) included those on improved processing and enrichment of cassava products, HIV/AIDS prevention, home garden planning and bygiene. Highest adoption was recorded in nutrition and environment-related technologies by women who participated in both Women-in-Agriculture (WIA) and RTEP followed by participants in only WLA groups, RTEP only and lastly non-participants in both WIA and RTEP. Educational qualification $(r=0.180)$, farm size $(r=0.150)$, membership of cooperatives $(r=0.155)$, annual income $(r=0.801)$ and contact with extension agents $(r=0.285)$ had significant positive correlation with adoption of nutrition technologies. Women categories differed significantly with respect to adoption of nutrition $(F=56.572 ; p<0.05)$. and environment-related technologies $(F=29.365 ; p<0.05)$. Serious constraints to adoption of technologies included inadequate infrastructural development $(\bar{X}=3.99)$, inability to afford inputs $(\bar{X}=3.98)$, poor access to capital and credit $(\bar{X}=3.97)$, low level of education $(\bar{X}=3.95)$ and low extension contact $(\bar{X}=3.92)$. The findings underline the achievements of IF AD in targeting women. More interventions on housebold food, nutrition and environment are recommended to address the barriers to cassava technology adoption and encourage more women's participation.
\end{abstract}

Keywords: Women, nutrition, environment, cassava technology adoption, IFAD, Nigeria. 


\section{Introduction}

Root and tuber crops constitute important and often major components in traditional diets of Africans. Cassava (Manibot esculenta crantz) is one of the most important crops in Africa. It is very prominent in Nigerian diets and income generation. Cassava is one of the principal root and tuber crops of the tropics. Like other roots and tubers it is rich in carbohydrate, calcium, vitamins B and C but nutrient composition differs according to variety, age of harvested crop, soil condition, climate and processing method [International Institute for Tropical Agriculture (IITA, 2009)]. Cassava has been very prominent in Nigerian diets as it is consumed about 1-4 times per week by over $80 \%$ of the households [nternational Fund for Agricultural Development/Food and Agriculture organization (IFAD/FAO (2004)]. It has been described as a food security crop, income earner and poverty reducer (Omueti, 2006; Ashaye, 2009). Nigeria is the largest producer of cassava with about 38 million metric tons per annum ahead of other world producers like Brazil and Thailand (Tijani and Thomas, 2011).

Various problems such as very low protein content, tedious processing to reduce the naturally occurring cyanogens and waste disposal in the cycle are associated with cassava value-chain which can only be solved with appropriate technologies. To address low protein content of roots and tubers particularly cassava, Food and Agriculture Organization (FAO), (2008), World Health Organization (WHO), (2006) and (FAO), (2011), recommended the need for fortification and enrichment of staple foods. The consumption of soybean was also encouraged.

Technologies and information to enhance production and nutrition as well as reduce environmental hazards were disseminated under IFAD assisted Root and Tuber Expansion Programme (RTEP). According to Pruss-Ustun and Corvalan (2006), about one-third of Africa's disease burden is attributable to environmental hazards. The major contributing risk factors to health hazards are environmental pollution, poor access to safe water, air pollution from fuel combustion, and poor sanitation and hygiene. Nweke and Sanders (2009) state that poor sanitation account for most of Africa's environmentally related disease burden which require appropriate safeguards. Prevention of human contact with wastes, hazards associated with lack of healthy food, clean water and healthful housing, control of vectors and management of waste produced by human activities which are associated with cassava value chain is very important in this regard.

In Nigeria, cassava was initially a women's crop (Omueti, 2006) while other food crops like yam, maize and tree crops were for the men. This could be connected to the fact that women have limited access to fertile or good farmland and cassava thrived in the seemingly poor land apportioned to women. Pinstrup-Anderson, (1984) states that linkages in food, nutrition and health are mediated through women in their role as managers of household food, nutrition and healthcare. IFAD targeted women in line with the objective of UN systems and gender was mainstreamed to ensure equal access to and control over resources and benefits.

IFAD supported cassava development in Nigeria through the Cassava Multiplication Programme (CMP) from1987 to 1997 to address the declining production. Strategies to address, gender issues and target women with production, processing and utilization information/technologies were implemented under Women-In- Agriculture (WIA) programme. This was followed by the Root and Tuber Expansion Programme (RTEP) which was designed and implemented from 2003 to 2009 RTEP as a follow on to the CMP to consolidate the gains of CMP and address associated problems such as storage and processing (NFRA/FMAWR, 2010). There was redesign of RTEP from state-wide strategy to community-based (CB) in order to concentrate effort. The CB-RTEP strategy focused on establishment of processing centres and enterprise 
management in mixed sex groups. Hence, out-growers and processing groups made up of males and females from five (5) selected communities per Local Government Area (LGA) were involved per State. Processing centres were established, equipped with processing machines, product markets were created with coupled extension services delivery (Abia State ADP, 2010; Rivers State ADP, 2010). Four categories of women were therefore identified in the study area: Participants in

- only Women-In- Agriculture (WIA) programmme group,

- only Root and Tuber Expansion Programme (RTEP) group,

- both Women-In- Agriculture (WIA) programmme and Root and Tuber Expansion Programme (RTEP), and

- Non Women-In- Agriculture (WIA) programmme and Root and Tuber Expansion Programme (RTEP) participants.

\section{Purpose and objectives}

The study assessed the adoption of nutrition and environment-related technologies disseminated at different stages of IFAD's intervention. Specifically the study described the socio-economic characteristics of women cassava farmers, identified nutrition and environment-related technologies and information disseminated to them, examined the extent of adoption and constraints to adoption.

\section{Method}

The study area, South East agro-ecological zone of Nigeria comprises of nine (9) States, five (5) and four (4) of which belong to the South East and South South geo-political zones respectively. The vegetation comprises rain forest in the eastern states and mangrove forest of the coastal states. Major activities of the people are farming of arable and tree crops, livestock and fisheries as well as processing and marketing. Cassava is the major staple crop of most farming families. The eight States in south-east agro-ecological zone (except Bayelsa State) out of nine (9) participated in the IFAD/FGN/RTEP with 17 other states and Federal Capital Territory (FCT), Abuja, in the Federation.

The sampling procedure involved two major stages:

Rapid appraisal visit to the eight participating States for preliminary information which assisted in drawing the sample; four states (Imo, Cross River, Anambra and Rivers) were eventually purposively selected to reflect varying degrees of implementation situation as at October, 2012. The sample was drawn through a multi stage process involving:

- Selection of four States

Two Local Government Areas (LGAs) out of five which benefited from CB-RTEP processing facilities were selected per state;

- One RTEP group was selected per LGA= (2 groups per State), 10 women members per group $\times 2=20$ per state $\times 4=80$ (total in the sample); 
- Two WIA groups were selected per state (same LGAs as CB-RTEP groups) for 20 WIA group members were randomly selected- 20 per state $x 4=80$ (total in the sample);

- Ten (10) other women respondents who at a time or the other belonged to WIA and RTEP groups were purposively selected-10 per State (because they were few) $5 \times 4=40$ (total in the sample).

- Twenty (20) respondents who were not members of either group were selected (10/LGA)20 per state $\mathrm{x} 4=80$ (total in the sample)

Total sample size $=280(70 \times 4$ States $)$

\section{Data collection instrument/procedure}

Focus group discussion (FGD) was used to interact with the groups. Interview schedule was used to triangulate information and obtain individual responses to the questionnaire. The questionnaire for women comprised sections on socio-economic characteristics, awareness, trial and adoption of HHFNH technologies/information. The ADP was involved.

\section{Measurement of variables}

Years of schooling, cooperative membership (number), annual income in Naira $(\mathrm{N})$, contact with extension service (number/annum)

Adoption score was obtained in 3 stages: Awareness $=1$, trial=2, Adoption=3. (

Adoption score per technology ranges from 0-6.

Adoption score for Nutrition- related technologies $=6 \times 30=180$

Adoption score for environment- related technologies $=6 \times 16=96$

Constraint was measured: 4-point rating; Very serious $=4$, serious $=3$, little serious $=2$, not serious $=1$.

Ho 1: No significant relationships between socio-economic characteristics and adoption of technologies,

Ho 2: There is no significant difference among the four categories (WIA only, RTEP only, both WIA and RTEP and non WIA/RTEP) with respect to technology adoption.

\section{Results and discussion}

\section{Socio-economic characteristics of the respondents}

Table 1 shows that the grand mean values for the women were: age (47.73years), farm size (2.5ha), family size (6 persons) and farm farming experience (21.4years), cooperative membership (2nos), contact with extension service (about 3per annum), years of formal education (6.5years) and annual income (N171,218 or $\$ 1063 /$ annum) varied among the categories of women. RTEP women were older (51.18years). The findings of Salau et al., (2013) which gives women agro-processors' mean age 
as 38years and mean monthly income of N18,540 shows just slight variation. Characteristics such as small size of farms, few extension contact and low income $\$ 1063 /$ annum are indications of vulnerability of the respondents. However, RTEP, RTEP/WIA categories had more extension contact (about 6times/annum) as at survey period than non RTEP/WIA and WIA categories, while WIA category earned more income (N224,500/annum) which could probably be due to the fact that they were exposed to agricultural information and technologies much earlier than the other categories. The WIA programme started in 1990 to address women's production constraints (WIA handbook, 1990). Those who participated in only RTEP had more mean years of schooling (9.31years). This could be attributed to the fact that they were younger and attended up to secondary school level. However women who did not participate in either program had the least years of schooling (4.36) which tend to agree with the finding that education positively correlates with participation in agricultural development programmes (Nlerum and Wobuoma, 2011).

Table1: Means of selected socio-economic characteristics of the respondents

\begin{tabular}{|c|c|c|c|c|c|}
\hline Characteristics & $\begin{array}{l}\text { Non } \\
\text { WIA/RTEP } \\
(\bar{X})\end{array}$ & $\begin{array}{l}\text { RTEP } \\
(\bar{X})\end{array}$ & $\begin{array}{l}\text { WIA } \\
(\bar{X})\end{array}$ & $\begin{array}{l}\text { WIA/RTEP } \\
(\bar{X})\end{array}$ & $\begin{array}{l}\text { Grand Mean } \\
(\bar{X})\end{array}$ \\
\hline Age (years) & 47.54 & 44.23 & 51.18 & 47.97 & 47.73 \\
\hline Family size & 6.03 & 6.60 & 6.23 & 6.26 & 6.29 \\
\hline farm size & 2.44 & 2.07 & 2.81 & 2.78 & 2.53 \\
\hline $\begin{array}{l}\text { Farming } \\
\text { experience }\end{array}$ & 21.44 & 17.36 & 25.15 & 21.60 & 21.39 \\
\hline $\begin{array}{l}\text { Cooperative } \\
\text { membership }\end{array}$ & 1.29 & 2.23 & 1.85 & 2.37 & 1.94 \\
\hline Extension contact & 1.86 & 4.26 & 1.72 & 4.57 & 3.10 \\
\hline \begin{tabular}{|l} 
Years \\
education
\end{tabular} & 4.36 & 9.31 & 6.11 & 6.28 & 6.52 \\
\hline Annual income & 150,000 & 154,375 & 224,500 & 156,000 & 171,218 \\
\hline (Monthly) (N) & $(12500)$ & (12864) & (18708) & $(13000)$ & (14268) \\
\hline
\end{tabular}

\section{Adoption of Nutrition related technologies/information}

Table 2 shows technology adoption indices of the respondents for each technology by women category: WIA, RTEP, WIA+RTEP and non- WIA/RTEP. This shows that programme 
participants adopted technologies more than non-participants. The adoption of some technologies by non participants in cassava development programmes could be as a result of multiplier effect or they belong to other groups or had learnt about technologies from friends and neighbours. In FGD sessions some non-RTEP/WIA members confessed have learnt from friends and relative. Adoption of odourless fufui ( $\bar{X}=4.61)$ and high quality garri $(\bar{X}=4.43)$ had the highest mean adoption indices among programme participants and non participants. The technologies with low mean adoption indices (MTAI) such as mechanical drying $(\bar{X}=1.74)$ preservation of tubers $(\bar{X}=1.23)$, organic farming $(\bar{X}=1.79)$ could be due to high cost, complexity or low level of knowledge of farmers and processors. Batz et al., (2003), observed that technologies that are adopted rapidly are most likely to be profitable than those with low rates of adoption because the benefits occur faster as the ceiling of adoption is achieved earlier, all other things being equal.

Some technologies related to snacks production from mixture of high quality cassava flour (HQCF) and composite wheat flour recorded high indices (adoption index $=5.22$ ), soyabean utilization (adoption index $=5.18$ ) is an indication that adoption was high for WIA group. Lowest adoption was achieved among non-participants. This could be responsible for their lower income. This is in line with Ezeburio et al., (2010) that output of adopters of improved cassava varieties was greater than that of non adopters.

Table 2: Adoption score of nutrition related technologies disseminated

\begin{tabular}{|c|c|c|c|c|c|c|c|c|c|}
\hline \multirow{3}{*}{$\begin{array}{l}\text { Improved } \\
\text { technologies/information }\end{array}$} & \multicolumn{8}{|c|}{ Categories } & \multirow{3}{*}{ MTAI } \\
\hline & \multicolumn{2}{|c|}{$\begin{array}{l}\text { Non } \\
\text { RTEP/WI } \\
\text { A }\end{array}$} & \multicolumn{2}{|c|}{ RTEP } & \multicolumn{2}{|l|}{ WIA } & \multicolumn{2}{|c|}{ WIA/RTEP } & \\
\hline & Mean & SD & Mean & SD & Mean & SD & Mean & SD & \\
\hline \multicolumn{10}{|l|}{ NUTRITION RELATED } \\
\hline Drying (mechanical) & 1.14 & .52 & $3.18^{*}$ & .79 & 1.21 & .57 & 2.20 & .84 & 1.74 \\
\hline Cooling/Freezing of products & 2.11 & .53 & 2.21 & .88 & 2.30 & .48 & $3.12 *$ & .42 & 2.43 \\
\hline $\begin{array}{l}\text { Sun drying-hygienic and nutrient } \\
\text { conserving }\end{array}$ & 2.31 & .52 & $5.28 *$ & .42 & $3.80 *$ & .42 & $3.29 *$ & .32 & $3.67 *$ \\
\hline Fermenting & 2.82 & .42 & $3.23 *$ & .48 & $3.22 *$ & 3.42 & $3.27 *$ & .48 & $3.13 *$ \\
\hline Preservation of cassava tubers & 1.20 & .52 & 1.26 & .52 & 1.23 & .48 & 1.30 & .02 & 1.23 \\
\hline Improved frying method & .59 & .32 & $3.23 *$ & .67 & 2.20 & .00 & $3.25 *$ & .53 & 2.87 \\
\hline $\begin{array}{l}\text { Food enrichment with high protein } \\
\text { products }\end{array}$ & 2.14 & .70 & $3.19 *$ & .99 & $4.90^{*}$ & .88 & $5.30 *$ & .04 & $3.88 *$ \\
\hline Home garden planning for variety & 2.23 & .00 & $3.15^{*}$ & .53 & $4.87 *$ & .82 & $3.24 *$ & .52 & $3.39 *$ \\
\hline
\end{tabular}




\begin{tabular}{|c|c|c|c|c|c|c|c|c|c|}
\hline Exclusive breast feeding & 2.27 & .47 & $3.16^{*}$ & .70 & $3.25^{*}$ & .53 & $3.15^{*}$ & .53 & 2.96 \\
\hline Complementary feeding-enriched & 1.19 & .32 & 2.56 & .70 & $4.17^{*}$ & .82 & $3.27 *$ & .48 & 2.86 \\
\hline Increased vegetable consumption & 2.28 & .08 & $3.60 *$ & .70 & $4.15^{*}$ & .53 & $3.42 *$ & .48 & $3.36 *$ \\
\hline Fruit consumption & 2.20 & .47 & $3.16^{*}$ & .70 & $3.15^{*}$ & .53 & $3.25 *$ & .53 & 2.94 \\
\hline Soybeans utilization & 2.19 & .32 & 2.16 & .70 & $5.18^{*}$ & .79 & $3.85^{*}$ & .71 & $3.34 *$ \\
\hline $\begin{array}{l}\text { Processing techniques to conserve } \\
\text { nutrients }\end{array}$ & 2.81 & .32 & $3.16^{*}$ & .70 & $4.10^{*}$ & .52 & $3.56^{*}$ & .70 & $3.41 *$ \\
\hline $\begin{array}{l}\text { Identification of signs of } \\
\text { malnutrition and diseases }\end{array}$ & 2.45 & .32 & $3.48^{*}$ & .47 & $3.98^{*}$ & .07 & $4.25^{*}$ & .71 & $3.54 *$ \\
\hline Food combination & 2.19 & .32 & $3.20 *$ & .82 & $4.25^{*}$ & .71 & $4.42^{*}$ & .52 & $3.51 *$ \\
\hline Adequate/balance diet & 2.57 & .32 & $3.35^{*}$ & .63 & $4.21 *$ & .88 & $4.12^{*}$ & .48 & $3.56 *$ \\
\hline Organic farming & 1.21 & .32 & 1.41 & .74 & 2.34 & .52 & 2.22 & .48 & 1.79 \\
\hline $\begin{array}{l}\text { Behavioral change on specific } \\
\text { nutritional issues }\end{array}$ & 2.23 & .67 & $3.11 *$ & .52 & 3.27 & .48 & 3.28 & .42 & 2.97 \\
\hline Attractive and hygienic packaging & 1.41 & .32 & $4.20^{*}$ & .92 & 2.30 & .67 & $3.88^{*}$ & .42 & 2.95 \\
\hline Adequate flavouring and spicing & 2.11 & .32 & 2.21 & .57 & $3.22 *$ & .42 & $3.27 *$ & .48 & 2.70 \\
\hline $\begin{array}{l}\text { Addition of products fortified with } \\
\text { vitamins }\end{array}$ & 2.25 & .53 & $3.23 *$ & .95 & $3.79 *$ & .48 & $3.30^{*}$ & .00 & $3.14 *$ \\
\hline $\begin{array}{l}\text { Heat control in vitamins and } \\
\text { protein preparation }\end{array}$ & 2.30 & .67 & $3.21 *$ & .88 & $4.23^{*}$ & .48 & $3.89 *$ & .32 & $3.47 *$ \\
\hline Child spacing for good feeding & 2.74 & .70 & $3.14 *$ & .82 & $3.83^{*}$ & .48 & $3.26^{*}$ & .52 & $3.24 *$ \\
\hline $\begin{array}{l}\text { Care giving to special household } \\
\text { members-aged, sick }\end{array}$ & 2.24 & .52 & $3.18^{*}$ & .63 & $3.68^{*}$ & .48 & $3.27 *$ & .48 & $3.04 *$ \\
\hline Production of HQCF & 2.16 & .70 & $4.16^{*}$ & .52 & $3.21 *$ & .57 & $4.25^{*}$ & .53 & $3.44 *$ \\
\hline $\begin{array}{l}\text { Snacks production from mixture of } \\
\text { HQCF\& composite wheat flour }\end{array}$ & 2.20 & .35 & 2.19 & .88 & $5.22^{*}$ & .63 & $3.30^{*}$ & .00 & $3.05^{*}$ \\
\hline Production of high quality garri & $3.14^{*}$ & .52 & $5.18^{*}$ & .79 & $4.20^{*}$ & .94 & $5.22 *$ & .63 & $4.43 *$ \\
\hline Production of odourless $f u f u$ & $3.19 *$ & .32 & $5.17 *$ & .48 & $4.89 *$ & .42 & $5.21 *$ & .57 & $4.61 *$ \\
\hline
\end{tabular}




\begin{tabular}{|l|l|l|l|l|l|l|l|l|l|}
\hline $\begin{array}{l}\text { Use of micro-nutrient enriched } \\
\text { vitamins products }\end{array}$ & 2.00 & .00 & 2.27 & .48 & $3.17^{*}$ & .48 & $3.22^{*}$ & .79 & $\mathbf{2 . 6 6}$ \\
\hline
\end{tabular}

*Adoption index $\geq 3=$ Adoption; MTAI= Mean Technology Adoption Index

\section{Adoption scores for environment related technologies}

The distribution of respondents by technology adoption of environment related technologies disseminated is presented in Table 3. The results showed that participants in WIA and RTEP had the highest technology adoption indices in environment related information and technologies. The result showed that the highest mean adoption index was recorded for HIV/AIDS prevention measures such as avoidance of unsterilized tools (MTAI $=4.50)$ of which women participants in RTEP had $\bar{X}$ AI $=5.30$, followed by WIA/RTEP group $(\bar{X}$ AI $=5.25)$, WIA, non-RTEP/WIA groups with $\bar{X}$ AI $=4.25$ and 3.20 respectively. Other information and technologies with high adoption indices included refuse disposal (MTAI=4.39), environmental sanitation (MTAI=4.13), construction of toilet/latrine (MTAI=3.95), effluent disposal (MTAI=3.92), personal hygiene (MTAI=3.88) and hand washing $(\mathrm{MTAI}=3.75)$ all of which were least adopted by non-programme participants. Fuel efficient and green technologies were not adopted ( $\bar{X}$ AI $=1.27$ ) probably due to dearth of technology or they were not disseminated. In terms of water treatment among others, the results also indicated that highest adopters $(\bar{X} \mathrm{AI}=3.62)$ were WIA participants. This was closely followed by WIA/RTEP participants $(\bar{X}$ AI $=3.28)$, RTEP ( $\bar{X}$ AI $=3.21$ ) and non-RTEP/WIA ( $\bar{X}$ AI $=2.21$ ). The overall result shows that non- participants in RTEP and WIA ranked lowest in adoption of environment-related technologies while the highest adoption was recorded by participants in both WIA and RTEP. The results suggest women participants in IFAD interventions on cassava in the study area adopted information and technologies due to enhanced access to information, knowledge and inputs including credits.

Table 3: Adoption scores of environment related technologies

\begin{tabular}{|c|c|c|c|c|c|c|c|c|c|}
\hline \multirow{3}{*}{$\begin{array}{l}\text { IMPROVED } \\
\text { TECHNOLOGIES }\end{array}$} & \multicolumn{8}{|c|}{ CATEGORIES } & \multirow[t]{3}{*}{ MTAI } \\
\hline & \multicolumn{2}{|c|}{$\begin{array}{l}\text { Non } \\
\text { RTEP/WI } \\
\text { A }\end{array}$} & \multicolumn{2}{|l|}{ RTEP } & \multicolumn{2}{|l|}{ WIA } & \multicolumn{2}{|c|}{$\begin{array}{l}\text { WIA/ } \\
\text { RTEP }\end{array}$} & \\
\hline & Mean & SD & Mean & SD & Mean & SD & Mean & SD & \\
\hline \multicolumn{10}{|l|}{ ENVIRONMENT RELATED } \\
\hline HIV/AIDS prevention measures & $3.20 *$ & .47 & $5.30^{*}$ & .82 & $4.25^{*}$ & .71 & $5.25 *$ & .53 & $4.50 *$ \\
\hline Zero status/HIV Test & 2.21 & .32 & $3.22 *$ & .79 & $3.16^{*}$ & .82 & $3.25 *$ & .53 & 2.96 \\
\hline Confidentiality & 2.27 & .47 & 2.21 & .74 & 2.60 & .52 & 2.24 & .52 & 2.32 \\
\hline
\end{tabular}




\begin{tabular}{|c|c|c|c|c|c|c|c|c|c|}
\hline $\begin{array}{l}\text { Adequate nutrition for HIV } \\
\text { positive and other diseases }\end{array}$ & 1.74 & .70 & $3.23^{*}$ & .82 & $4.17^{*}$ & .48 & $3.18^{*}$ & .42 & $3.08 *$ \\
\hline $\begin{array}{l}\text { Care for HIV positive and other } \\
\text { disease sufferers }\end{array}$ & 1.24 & .70 & 2.23 & .82 & $3.24 *$ & .70 & $3.17 *$ & .48 & 2.47 \\
\hline $\begin{array}{l}\text { Prevention of malaria \& other } \\
\text { diseases by netting }\end{array}$ & 2.24 & .70 & $3.18^{*}$ & .63 & $3.92 *$ & .48 & $3.26^{*}$ & .52 & $3.15 *$ \\
\hline Hand washing & $3.25 *$ & .53 & $3.23^{*}$ & .67 & $4.23^{*}$ & .82 & $4.30 *$ & .44 & $3.75^{*}$ \\
\hline Personal hygiene & $3.20^{*}$ & .47 & $3.87 *$ & .48 & $4.18^{*}$ & .42 & $4.26^{*}$ & .52 & $3.88 *$ \\
\hline Water treatment & 2.21 & .32 & $3.21 *$ & .88 & $3.62 *$ & .79 & $3.28 *$ & .42 & $3.08 *$ \\
\hline $\begin{array}{l}\text { Use of fuel efficient/green } \\
\text { cooking technologies }\end{array}$ & 1.21 & .32 & 1.39 & .74 & 1.25 & .00 & 1.25 & .53 & 1.27 \\
\hline Environmental sanitation & $3.90^{*}$ & .47 & $4.18^{*}$ & .63 & $4.19 *$ & .32 & $4.26^{*}$ & .52 & $4.13 *$ \\
\hline Refuse disposal & $3.92 *$ & .47 & $4.34^{*}$ & .63 & $4.19 *$ & .32 & $5.12 *$ & .52 & $4.39 *$ \\
\hline Effluent disposal & 2.46 & .47 & $4.18^{*}$ & .63 & $3.37 *$ & .32 & $5.66^{*}$ & .52 & $3.92 *$ \\
\hline $\begin{array}{l}\text { Construction of toilets and } \\
\text { latrines }\end{array}$ & $3.20^{*}$ & .47 & $3.76^{*}$ & .63 & $3.19 *$ & .32 & $5.65^{*}$ & .52 & $3.95 *$ \\
\hline $\begin{array}{l}\text { Improved smoke control during } \\
\text { frying }\end{array}$ & 1.25 & .53 & 2.19 & .74 & $3.23 *$ & .48 & $4.28 *$ & .42 & 2.74 \\
\hline $\begin{array}{l}\text { Consult specialists for solution to } \\
\text { health problems }\end{array}$ & 2.24 & .70 & $3.24 *$ & .70 & $3.22^{*}$ & .92 & $3.28 *$ & .42 & 2.95 \\
\hline
\end{tabular}

*Adoption index $\geq 3=$ Adoption; MTAI= Mean Technology Adoption Index

\section{Relationship between respondent's socio-economic characteristics and adoption of farm technologies}

Educational qualification $(\mathrm{r}=0.180)$, farm size $(\mathrm{r}=0.150)$, membership of cooperatives $(\mathrm{r}=0.155)$, annual income $(\mathrm{r}=0.801)$ and contact with extension agents $(\mathrm{r}=0.285)$ had significant positive correlation with adoption of nutrition technologies. This implies that the more educated, with larger farm size, more cooperative membership, higher income and more contact with extension agents adopted nutrition related technologies more. The findings agree with earlier adoption studies like (Koyenikan and Anyanwu, 2011) that adoption positively correlates with contact with extension service.

These variables portend empowerment with knowledge, information and capital to achieve adoption for better living standard. It is noteworthy that age and farming experience negatively 
correlated although not significant meaning that the older women with longer years of farming experience were less likely to adopt nutrition related technologies.

Membership of cooperatives $(r=0.188)$, annual income $(r=0.251)$ and contact with extension agents $(r=0.274)$ had significant positive correlation with adoption of environment related technologies. This means that those who belong to cooperatives, earn more and had regular contact with extension agent are more likely to adopt the technologies.

Table 5: Relationship between respondents' socio-economic characteristics and adoption of technologies

\begin{tabular}{|l|l|l|l|l|l|l|}
\hline \multirow{2}{*}{ Independent variables } & \multicolumn{3}{l|}{ Adoption of technologies (Index score) } \\
\cline { 2 - 7 } & Environ & P-value & Decision & Nutrition & P-value & Decision \\
\cline { 2 - 8 } & $\mathbf{r}$ & & & $\mathbf{r}$ & & \\
\hline Age (years) & 0.028 & 0.211 & Not sig. & -0.034 & 0.214 & Not sig. \\
\hline Family size & 0.039 & 0.232 & Not sig. & 0.006 & 0.304 & Not sig. \\
\hline Educational qualification & 0.081 & 0.249 & Not sig. & $0.180^{*}$ & 0.038 & Sig. \\
\hline Farm size & 0.056 & 0.267 & Not sig. & $0.150^{*}$ & 0.049 & Sig. \\
\hline Farming experience & 0.007 & 0.301 & Not sig. & -0.076 & 0.297 & Not sig. \\
\hline Membership of cooperatives & $0.188^{*}$ & 0.032 & Sig. & $0.155^{*}$ & 0.041 & Sig. \\
\hline Annual Income & $0.251^{*}$ & 0.006 & Sig. & $0.801^{*}$ & 0.000 & Sig. \\
\hline Contact with extension agents & $0.274^{*}$ & 0.000 & Sig. & $0.285^{*}$ & 0.000 & Sig. \\
\hline
\end{tabular}

*Significant at $5 \%$ level.

\section{Test of difference in adoption of technologies among women groups (ANOVA)}

Table 5 shows that there were significant differences among the 4 categories of women respondents (WIA only, RTEP only, WIA and RTEP and non WIA/RTEP) with respect to adoption of technologies. The four categories of women significantly $(F=56.572 ; \mathrm{p}=0.000)$ differed in their adoption of nutrition related technologies with participants in WIA and RTEP having highest mean adoption (114.12), followed by WIA (109.46), RTEP (96.38) and Non-WIA/RTEP (65.96). Post Hoc test showed that mean adoption for both RTEP and WIA participants were not significantly different from WIA only but significantly different from mean values for participants in RTEP only and non-participants in WIA/RTEP. This could imply that nutrition education and practical were 
emphasized at different phases of intervention of IFAD. Adoption seemed to have been achieved at different phases but non participants recorded less adoption.

The categories of women differed significantly $(\mathrm{F}=29.365 ; \mathrm{p}=0.000)$ with respect to environment related technology adoption with highest mean for WIA and RTEP participants (125.83), WIA (105.65), RTEP (102.41) and non-WIA/RTEP (37.28). Post Hoc test showed that mean adoption for RTEP only and WIA participants were not significantly different from each other but were significantly different from mean values for participants in both WIA and RTEP as well as non-participants in WIA/RTEP. Adoption indices for technologies related to the environment were generally lower than for nutrition probably due to less material reward or immediate benefit accruable. High adoption among RTEP women could have resulted from efforts made by IFAD assisted RTEP to emphasize sanitation and health issues among the processing groups. These included construction of modern toilets and effective fume and effluent disposal at the processing centres.

Adoption of technologies for production and processing activities and market information is on the increase as reported by many states in review workshops (IFAD/FGN/FMARD, 2005; Abia; Akwa Ibom, 2008). Agu (2001) posited that WIA programme needs to be expanded to address the current realities and needs of women farmers. Rural $\mathrm{HIV} / \mathrm{AIDS}$ prevention campaign/awareness has continued to be implemented and it has made appreciable impact (IFAD/FGN/FMARD, 2005; Akwa Ibom ADP, 2008).

Table 5: Difference in adoption of technologies among women groups

\begin{tabular}{|c|c|c|c|c|c|}
\hline Adoption & $\begin{array}{l}\text { No. of } \\
\text { cases }\end{array}$ & Mean & $F$ value & $\begin{array}{l}P \text { - } \\
\text { value }\end{array}$ & \\
\hline Nutrition technol & & & & & \\
\hline Non-WIA/RTEP & 80 & $65.96^{\mathrm{d}}$ & \multirow{4}{*}{$56.572^{*}$} & \multirow{4}{*}{0.000} & \multirow{4}{*}{ Significant } \\
\hline WIA/RTEP & 40 & $114.12^{\mathrm{a}}$ & & & \\
\hline RTEP & 80 & $96.38^{c}$ & & & \\
\hline WIA & 80 & $109.46^{\mathrm{a}}$ & & & \\
\hline Environment tecl & & & \multirow{5}{*}{$29.365^{*}$} & \multirow{5}{*}{0.000} & \multirow{5}{*}{ Significant } \\
\hline Non-WIA/RTEP & 80 & $37.28^{\mathrm{d}}$ & & & \\
\hline WIA/RTEP & 40 & $125.83^{a}$ & & & \\
\hline RTEP & 80 & $102.41^{b}$ & & & \\
\hline WIA & 80 & $105.65^{b}$ & & & \\
\hline
\end{tabular}

* Significant at the 5\% level 
Constraints faced by women in the adoption of nutrition and environment-related information/technologies

The respondents' most serious constraints to adoption of nutrition and environment related information/technologies were inadequate infrastructural development $(\bar{X}==3.99)$, inability to afford inputs/equipment $(\bar{X}=3.98)$, poor access to capital and credit back up adoption $(\bar{X}=3.97)$, low level of education $(\bar{X}=3.95)$, low extension contact $(\bar{X}=3.92)$, inadequate knowledge and skills $(\bar{X}=3.17)$, dearth of technologies $(\bar{X}=2.83)$ and poor group cohesion $(\bar{X}=2.36)$. The importance of infrastructural development and technologies especially labour saving devices for processing operations to improve the living standards of rural population especially women cannot be over emphasized. The place of capital to acquire technologies by low income earners in addition, education, extension contact and group cohesion for empowerment in terms of material resources and knowledge for development is crucial for meaningful impact. These corroborate the findings of Salau et al., (2013) and Odebode and Adetunji (2010) that problems faced by women agro-processors and farmers respectively included inadequate capital and poor access to credit facility. The problems of inadequate knowledge, dearth of technologies could have resulted from low extension contact. This agrees with Nlerum and Wobuoma (2011) that poor access to project field officers was one of the major constraints in Fadama III in Nigeria.

Table 4: Constraints faced by women

\begin{tabular}{|l|l|l|}
\hline CONSTRAINTS & \multicolumn{2}{|l|}{} \\
\cline { 2 - 3 } & Mean & SD \\
\hline No time to attend training due to work load & 1.25 & .136 \\
\hline I do not have adequate knowledge and skills & & .134 \\
\hline Language barrier & $3.17 *$ & .198 \\
\hline Low contact with extension agents & 1.08 & .320 \\
\hline Inadequate training materials/input/equipment & $3.92 *$ & .342 \\
\hline $\begin{array}{l}\text { Poor access to capital and credit to invest/to acquire } \\
\text { technology }\end{array}$ & $3.97 *$ & .404 \\
\hline Inadequate infrastructural facilities & & \\
\hline Dearth of efficient technologies & $3.99 *$ & .311 \\
\hline Poor group cohesion & $2.83 *$ & .272 \\
\hline Discouraged by my husband & $2.36 *$ & .286 \\
\hline
\end{tabular}




\begin{tabular}{|l|l|l|}
\hline Low level of education & $3.95 *$ & .162 \\
\hline
\end{tabular}

$* \geq 2.5=$ serious constraints

\section{Implications for agricultural extension and food security in Africa}

This study has shown that group membership enhances adoption in women as adoption indices were higher for women group members (phases of IFAD intervention were associated with groups formed) than non-members/non participants. Adoption also increased with number of groups women participated in. The IFAD interventions programmes could have promoted extension contact. This buttresses the fact that there cannot be adequate substitute for contact with extension agents/facilitators of change process. More workers need to be engaged as this could address constraints such as inadequate knowledge and skills, dearth of technologies and poor group cohesion. Cassava value chain has witnessed tremendous development from IFAD's interventions having targeted women and achieved adoption of, nutrition, health and environment related technologies. Other programmes in Africa could emulate this comprehensive approach in order to make appreciable impact in improving standard of living of rural households. Cassava is an important crop in Nigeria and by extension Africa hence development of its value chain for enhanced adoption consequently income, healthy and environmentally safe population could target women without neglecting men.

\section{Conclusion and recommendations}

Women who were involved in cassava value chain were in their active years, smallholders, with low formal education, contact with extension service and income. Women who belonged to only WIA group were oldest while those who participated in only RTEP were youngest. Women who were more educated, with larger farm sizes, more cooperative membership, with higher income and had more contact with extension agents adopted nutrition related technologies more. The four categories of women significantly differed in their adoption of nutrition and environment related technologies with non-WIA/RTEP participants having the least mean adoption indices.

- The respondents' most serious constraints to adoption of nutrition and environment related information/technologies included inadequate infrastructural facilities, inability to acquire necessary inputs/equipment, poor access to capital and credit to back up adoption, low level of education, low extension contact, inadequate knowledge and skills, dearth of technologies and poor group cohesion.

- Based on the findings, the following are recommended:

- More interventions on cassava value chain should be encouraged by government, NGOs and communities.

- Women should be targeted and adequately mobilized to effectively participate in programmes for enhanced nutrition and environment related technology adoption

- Mass and group channels should be explored to complement extension agents' contact to reach more women with information and technologies on cassava value chain. This will help to build capacities on nutrition, health and environment-related technologies/information and address other constraints like

- Infrastructural development in communities and credit support to women by all the tiers of government, IFAD and other donors, private sector and community self help efforts will be 
necessary to consolidate the benefits derived from IFAD interventions and create enabling environment for enhance technology adoption.

\section{Acknowledgement and Disclaimer}

Data collection was supported by MEAS Project of USAID Grant MSU RC-06-3860. However, views expressed in this article do not represent those of USAID or the US government.

\section{References}

Abia State ADP. (2010). Internal project completion report. Root and Tuber Expansion Programme (RTEP). Abia State Agricultural Development Programme. pp5-9.

Adedoyin, S.F. (2011).

Environmental impact assessment (eia) and implication for agricultural and rural development. In Adedoyin S.F. Rural Agricultural and Environmental Sociology in Nigeria 2011. 799-809.

Ahmed, M.F. and Rahman, M. M. (2003).

Water supply \& sanitation: rural and low income urban communities, 2nd Edition, ITNBangladesh.

Ezeburio, N.C, Ironkwe, A.G., Ugbaja, C. I. and Okoro, B. O. (2010).

Adoption of improved cassava varieties by women in Umuahia agricultural zone of Abia State, Nigeria.Nigerian Journal of Rural Sociology, Vol.10 (1), 17-26.

Federal Ministry of Agriculture and Rural Development (FMARD). (2006).

Yearly statistics of agricultural production in Nigeria. Abuja: Federal Ministry of Agriculture and Natural Resources

Food and Agriculture Organisation (FAO). (2008).

Storage and processing of roots and tubers in the tropics. Rome: FAO Corporate Document Repository 2008, Agriculture and Consumer Protection.

FAO. (2002).

Cassava development in Nigeria a country case study towards a global strategy for cassava development.

Abuja: Department $\mathrm{f}$ Agriculture Federal Ministry of Agriculture and Natural Resources

FAO. (2005).

A review of cassava in Africa with country case studies on Nigeria, Ghana, the United Republic of Tanzania, Uganda and Benin, International Fund for Agricultural Development. Proceedings of the validation forum on the global cassava development strategy volume 2 .

FAO. (2006).

FAOSTAT, Food Security Statistics, Nigeria. Retrieved from http://www.fao.org/faostat/foodsciences/country/EN/Nigeria.pdf. Rome: .Food and Agriculture Organization of the United Nations.

Ibrahim H. Y. and Onuk, E.G. (2010).

The Impact of Root and Tuber Expansion Programme (RTEP) On Root and Tuber Crops

Production In Nasarawa State, Nigeria. Department of agricultural Economics and Extension, Nasarawa State University, Keffi, Nigeria. 
IITA. (2009).

International Institute of Tropical Agriculture. Annual Report. . 2009 Annual report. National Food Reserve Agency (NFRA).

Koyenikan, M. and Anyanwu, J.C. (2011).

Technology adoption behaviour of rice farmers in Ekpoma area of Edo State, Nigeria. Journal of Agriculture, Forestry and Fisheries. Vol. 12 (1). Faculty of Agriculture, Uniben, BeninCity. pp14-20.

Nlerum, F. E. and Wobuoma, E. (2011).

Participation in fadama III project and its socio-economic effect on rural families. Nigerian Journal of Rural Sociology, Vol.10(1), 39-48.

Nweke, O.C and Sanders, W.H. (2009).

Modern environmental health hazards: A public health issue of increasing significance in Africa. Environ Health Perspective 117(6): 863-870.

Odebode, S.O. and Adetunji, T. (2010).

Gender analysis of agricultural support services received by inland-valley (fadama II) famers in Oyo state Nigeria. Vol. 10(1), 47-66.

River State ADP. (2010)

Internal project completion report. Root and Tuber Expansion Programme (RTEP). River State Agricultural Development Programme., Nigeria.

Salau, E. S., Bello, D. and Alanji, J.E. (2013).

Access and use of resources by women agro-processors in central agricultural zone of Nasarawa State, Nigeria. Journal of Agricultural Extension. Vol. 17(2), 156-164.

Stephenson, K; Amthor, R; Mallowa, Nungo, R; Maziya-Dixon, B; Gichuki, S; Mbanaso, A \& Manary, M. (2010).

Consuming cassava as a staple food places children 2-5 years old at risk for inadequate protein intake, an observational study in Kenya and Nigeria. Nutrition Journal, Vol. 9.

Tijani, S.A and Thomas, K.A. (2011).

Effectiveness of Root and Tuber Expansion Programme on cassava farmers production in Remo Area of Ogun State, Nigeria. Orean Journal of Applied Sciences 4 (3)

Rivers State ADP. (2010).

Internal project completion report. Root and Tuber Expansion Programme (RTEP). Rivers State Agricultural Development Programme.

RTEP PIM. (2006).

Root and Tuber Expansion Programme (RTEP): Implementation manual. IFAD/FGN.

Ugwu, B.O., Felix, I. and Dixion, A.G.O.(1996).

Spread and performance of improved cassava varieties in Nigeria: a collaborative study of cassava in Africa, IITA, Paper No. 15, 20-26, Ibadan, Nigeria. 